\title{
Structure of central airways in current smokers and ex-smokers with and without mucus hypersecretion: relationship to lung function
}

\author{
J B M Mullen, J L WRight, B R WigGS, P D PARÉ, J C HOGG \\ From the Pulmonary Research Laboratory, University of British Columbia, St Paul's Hospital, Vancouver, \\ Canada
}

\begin{abstract}
Forty five patients who underwent thoracotomy and lung resection for tumour were studied to compare the structure of the central airways in current smokers and ex-smokers. The patients were divided into four groups: current smokers with mucus hypersecretion $(\mathrm{n}=15)$, current smokers without mucus hypersecretion $(n=14)$, ex-smokers with mucus hypersecretion $(n$ $=5$ ), and ex-smokers without mucus hypersecretion $(n=11)$. Quantitative histological studies of the airway wall showed no difference in gland size, smooth muscle, connective tissue, or Reid index between the groups. The central airways of patients with mucus hypersecretion showed increased mucosal inflammation. The five ex-smokers in whom mucus hypersecretion persisted after they had stopped smoking had both central and peripheral airways affected by the inflammatory response, and these patients also had an abnormal result in the nitrogen washout test.
\end{abstract}

\section{Introduction}

Cigarette smoking has been identified as the major risk factor for development of chronic obstructive pulmonary disease. Changes in central airways associated with prolonged cigarette smoking include mucus hypersecretion and mucous gland enlargement. ${ }^{1-4}$ The structural basis for mucus hypersecretion was thought to be enlargement of the bronchial glands, but a recent study has shown that it may be related to an inflammatory process in the central airways. ${ }^{5}$

The purpose of this study was to examine the effect of smoking habit on central airways structure and to determine whether the reduction in mucus hypersecretion associated with cessation of smoking was due to changes in severity of the inflammatory process in the airway wall or a reduction in size of the bronchial mucous glands. At the same time we attempted to determine whether persistence of mucus hypersecretion after cessation of smoking was associated with more severe airways disease. We used the standard clinical criteria for chronic bronchitis, con-

\footnotetext{
Address for reprint requests: Dr J C Hogg, Pulmonary Research Laboratory, St Paul's Hospital, 1081 Burrard Street, Vancouver, British Columbia V6Z IY6, Canada.
}

Accepted 15 June 1987 sisting of a history of a productive cough occurring on most days for at least three months in the year for at least two successive years. We have used the term mucus hypersecretion throughout to emphasise the clinical rather than pathological nature of the term.

\section{Methods}

\section{PATIENTS}

We studied 45 patients admitted to St Paul's Hospital, for resection of an upper lobe in $\mathbf{4 0}$ cases and a lung in five; in most this was for bronchogenic carcinoma. After the diagnosis had been made and surgery decided on, the study was explained to the patient and informed consent was obtained in all cases.

A modified British Medical Research Council questionnaire was used to assess cigarette smoking and cough and sputum history. An ex-smoker was defined as a subject who had ceased smoking at least four months before surgery. Mucus hypersecretion was defined as indicated in the introduction. There were 29 current smokers, 15 of whom had mucus hypersecretion; the ex-smoking group consisted of 16 patients, five of whom had mucus hypersecretion. In the group with mucus hypersecretion the patients had not been smoking for a mean of two (median 3.5) years. The mean interval since those in the group without mucus hypersecretion stopped smoking was 
10 (median 3) years (one patient was a long term exsmoker of 45 years).

\section{PULMONARY FUNCTION STUDIES}

Pulmonary function tests were performed within the week before surgery with an air conditioned pressure compensated volume displacement body plethysmograph. Flow was measured with a Fleisch No 3 pneumotachometer coupled to a Sanborn 270 differential pressure transducer (Sanborn Co, Wallham, Montana) and volume was measured with a Krogh spirometer coupled to a linear displacement transducer (type 300 NR; Shaevitz Engineering, Pennsauken, New Jersey). Functional residual capacity (FRC) was determined by the Boyle's law technique, ${ }^{6}$ and residual volume (RV) and total lung capacity (TLC) were calculated. Forced expiratory volume in one second $\left(\mathrm{FEV}_{1}\right)$, forced vital capacity (FVC), and maximal flows at $\left.50 \%\left(\dot{V}_{\max }\right)_{50}\right)$ and $25 \%\left(\max _{25}\right)$ of FVC were calculated from digitised flow and volume signals during forced expiratory manoeuvres. At least three expiratory efforts were produced and the forced expiratory manoeuvre with the largest sum of FEV ${ }_{1}$ and FVC was selected. Single breath nitrogen washout was performed as described by Buist and Ross ${ }^{7}$ and the slope of phase $3\left(\Delta N_{2} / l\right)$ was calculated. Diffusing capacity (transfer factor, TLCO) was measured by the steady state technique. Values were expressed as percentages of the predicted values according to the prediction formulae of Morris et al $^{8} \quad\left(\mathrm{FEV}_{1}, \mathrm{FVC}\right)$, Dosman etal ${ }^{9} \quad\left(\mathrm{~V}_{\max }{ }_{50}\right.$, $\left.\dot{V} \max _{25}\right)$, Buist and $\operatorname{Ross}^{7}\left(\Delta \mathrm{N}_{2} / 1\right)$, and Bates et al ${ }^{10}$ (TLCO).

\section{MORPHOLOGICAL STUDIES}

Surgically resected specimens were fixed in inflation with $10 \%$ formalin or $3 \%$ buffered glutaraldehyde by intrabronchial infusion at a constant pressure of $25 \mathrm{~cm} \mathrm{H}_{2} \mathrm{O}$ for 24 hours. They were then serially sliced in a sagittal plane.

Samples of five intrapulmonary cartilaginous airways from each specimen were selected and designated as "central" airways. Sections from areas showing bifurcation of airways, presence of tumour, or draining areas of obstructive pneumonitis were excluded. The sections were decalcified in $15 \%$ formic acid for 24 hours, processed for histological examination in the usual manner, and then cut at $5 \mu \mathrm{m}$ thickness and stained with haematoxylin and eosin. All measurements in cartilaginous airways were performed with a camera lucida and an Apple II computer assisted digitising board. The luminal diameter of each cartilaginous airway was measured as the maximum distance perpendicular to the long axis of the airway lumen. The areas of the lumen and wall (gland, cartilage, smooth muscle, and connective tis- sue) were measured by tracing each component and $\overrightarrow{0}$ expressing it as a percentage of the total tissue area. $\frac{\bar{O}}{\square}$ Whenever possible, the Reid index was calculated for $\overline{\frac{F}{\omega}}$ each airway by the method of Thurlbeck et al. ${ }^{3}$

The cartilaginous airways were graded by $\mathrm{a} \otimes$ modification of the pictorial grading method of Cosio s et al. ${ }^{11}$ Each airway was divided into quadrants and a $\vec{\circ}$ separate grade was determined (from 0 to 3 , normal $\overrightarrow{\vec{H}}$ to severe) for each quadrant according to the presence $\stackrel{\omega}{\omega}$ or absence and the severity of each of the following: $\overrightarrow{\vec{x}}$ mucosal (epithelial) inflammation, goblet cell metaplasia, squamous cell metaplasia, pigment deposition, $\stackrel{\vec{\sim}}{.}$ and mural inflammation affecting each of glands, $\overrightarrow{-}$ gland ducts, nerves, smooth muscle, and interstitium. The grading technique is subjective, and is based on a $\omega$

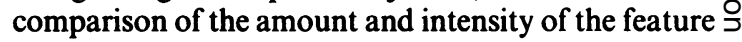
being graded (for example, inflammation) on the slide with a standard set of photographs that illustrate each $Z$ grade of each feature. A single score for each airway $\underset{\Phi}{ }$ was then determined for each variable by summing 3 the individual quadrant scores and expressing this $\stackrel{\Phi}{-}$ total as a percentage of the maximum possible score. $\overrightarrow{0}$ In addition, a score for inflammation of the cartilaginous airways was calculated as the sum of the six components, with the maximum possible score 600 .

The pathology of the peripheral airways (membranous and respiratory bronchioles) was assessed by the method of Wright et al. ${ }^{12}$ All airways had an $\frac{0}{\mathbb{Q}}$ internal diameter of under $2 \mathrm{~mm}$. A membranous $\triangle$ bronchiole was defined as an airway with a complete $\overrightarrow{\overrightarrow{0}}$ fibromuscular wall, while a respiratory bronchiole 3 was defined as partially alveolated.

The midsagittal slice was used for estimating the degree of emphysema by a modification of the pictorial grading method of Thurlbeck et al. ${ }^{13}$

\section{STATISTICAL ANALYSIS}

The relationship of smoking habit to pulmonary $\delta$ function, airways disease, and emphysema was examined by dividing the patients into two groups: patients $\mathrm{O}$ with current mucus hypersecretion who had had a productive cough occurring on most days for at least three months in the year for at least two successive preceding years and a control group who did not have $\sigma$ these symptoms. ${ }^{14}$ These groups were then sub- $N$ divided into current smokers and ex-smokers. A uni- N variate one way analysis of variance was used to 0 ascertain whether there were differences between groups.

\section{Results}

The effect of smoking habit on pulmonary function is $\cong$ shown in table 1. Flow rates and carbon monoxide $\stackrel{\square}{\varrho}$ diffusing capacity were similar in all groups. FRC waso 
Table 1 Pulmonary function data (mean (SD) percentages of predicted values)

\begin{tabular}{|c|c|c|c|c|}
\hline & \multicolumn{2}{|c|}{ No mucus hypersecretion } & \multicolumn{2}{|c|}{ Mucus hypersecretion } \\
\hline & Current smoker & Ex-smoker & Current smoker & Ex-smoker \\
\hline $\begin{array}{l}\text { No of patients } \\
\text { Age (years) } \\
\text { Cigarette years* }\end{array}$ & $\begin{array}{c}14 \\
59(9) \\
837(389)\end{array}$ & $\begin{array}{c}11 \\
61(11) \\
1113(937)\end{array}$ & $\begin{array}{c}15 \\
59(10) \\
1061(508)\end{array}$ & $\begin{array}{c}5 \\
63(10) \\
1176(1058) \dagger\end{array}$ \\
\hline $\begin{array}{l}\text { TLC } \\
\text { FRC } \\
\text { RV } \\
\text { FVC } \\
\text { FEV } \\
\text { FEV }_{1} / \text { FVC } \\
\operatorname{Vmax}_{50} \\
\operatorname{Vmax}_{25} \\
\Delta \mathrm{N}_{2} / 1 \\
\text { TLCO }\end{array}$ & $\begin{array}{c}110(18) \\
127(22) \ddagger \\
147(32) \\
95(17) \\
90(20) \\
69(9) \\
48(27) \\
37(24) \\
232(203) \\
98(39)\end{array}$ & $\begin{array}{c}98(13) \\
103(20) \\
117(33) \\
93(15) \\
95(16) \\
73(6) \\
62(20) \\
41(20) \\
198(156) \\
87(30)\end{array}$ & $\begin{array}{c}111(13) \\
128(22) \ddagger \\
141(38) \\
99(11) \\
94(19) \\
69(10) \\
60(35) \\
42(28) \\
157(106) \\
99(46)\end{array}$ & $\begin{array}{l}110(7) \\
124(18) \\
137(19) \\
98(15) \\
96(20) \\
68(9) \\
62(44) \\
44(30) \\
303(127) \ddagger \\
87(18)\end{array}$ \\
\hline
\end{tabular}

* Number of cigarettes per day multiplied by number of years smoked.

$t p<0.05$ for difference from both groups of current smokers.

$\pm \mathrm{p}<0.01$ for difference from ex-smokers without mucus hypersecretion.

TLC - total lung capacity; FRC - functional residual capacity; RV-residual volume; FVC-forced vital capacity; FEV -forced expiratory

volume in one second; $\mathrm{Vmax}_{50}, \mathrm{~V} \max _{25}-\operatorname{maximum}$ flow at $50 \%$ and $25 \%$ of $F V C ; \Delta \mathrm{N}_{2} / 1 \rightarrow$ slope of phase 3 of nitrogen washout curve;

TLco-transfer factor (diffusing capacity) for carbon monoxide.

increased in both groups of current smokers. Exsmokers with mucus hypersecretion were slightly older than the other groups and had a greater lifetime cigarette consumption than current smokers.

There were no differences in Reid index or measurements of gland size, smooth muscle, cartilage, or connective tissue in the central airways between the groups (table 2). Patients with mucus hypersecretion showed greater mucosal inflammation than the exsmokers without hypersecretion. Ex-smokers with mucus hypersecretion tended to have the most severe mucosal inflammatory process with greater $(p<$ $0.01)$ gland inflammation than the current smoking groups. The remaining inflammation parameters were similar in all groups. The current smokers had more goblet cell metaplasia than the ex-smokers. Exsmokers with mucus hypersecretion had significantly greater squamous cell metaplasia than the other three groups.

The ex-smokers with mucus hypersecretion also had significantly greater membranous and respiratory bronchiole inflammation than the other groups (table

Table 2 Central airways data (means (SD))

\begin{tabular}{|c|c|c|c|c|}
\hline & \multicolumn{2}{|c|}{ No mucus hypersecretion } & \multicolumn{2}{|c|}{ Mucus hypersecretion } \\
\hline & Current smoker & Ex-smoker & Current smoker & Ex-smoker \\
\hline $\begin{array}{l}\text { Structure* } \\
\text { Gland \% } \\
\text { Smooth muscle \% } \\
\text { Cartilage \% } \\
\text { Connective tissue \% } \\
\text { Reid index }\end{array}$ & $\begin{array}{c}4 \cdot 0(2 \cdot 0) \\
1 \cdot 8(0 \cdot 6) \\
18 \cdot 2(7 \cdot 3) \\
76 \cdot 0(7 \cdot 4) \\
0.37(0 \cdot 09)\end{array}$ & $\begin{array}{c}3 \cdot 5(2 \cdot 0) \\
2 \cdot 3(1 \cdot 3) \\
17 \cdot 9(4 \cdot 6) \\
76 \cdot 2(4 \cdot 1) \\
0 \cdot 33(0 \cdot 11)\end{array}$ & $\begin{array}{c}4.0(1.5) \\
2.5(1.1) \\
20.1(8.0) \\
73.4(8.6) \\
0.39(0.08)\end{array}$ & $\begin{array}{c}5.7(4.4) \\
1.8(0.3) \\
20.0(2 \cdot 2) \\
72.6(3.4) \\
0.41(0.09)\end{array}$ \\
\hline $\begin{array}{l}\text { Wall } \\
\text { Inflammation score } \\
\text { Mucosa } \\
\text { Glands } \\
\text { Gland ducts } \\
\text { Interstitium } \\
\text { Smooth muscle } \\
\text { Nerves } \\
\text { Total inflammation } \\
\text { Pigment }\end{array}$ & $\begin{array}{c}44(30) \\
27(10) \\
18(13) \\
14(12) \\
2(5) \\
4(3) \\
110(58) \\
16(6)\end{array}$ & $\begin{array}{c}34(18) \\
31(8) \\
23(18) \\
21(17) \\
1(1) \\
2(4) \\
112(53) \\
18(10)\end{array}$ & $\begin{array}{c}59(24) \S \\
28(12) \\
24(17) \\
21(15) \\
3(6) \\
7(8) \\
141(67) \\
15(10)\end{array}$ & $\begin{array}{c}65(14) \S \\
39(12)+\dagger \\
17(11) \\
26(18) \\
4(6) \\
2(2) \\
152(45) \\
18(8)\end{array}$ \\
\hline $\begin{array}{l}\text { Epithelium } \\
\text { Goblet cell metaplasia score } \\
\text { Squamous cell metaplasia score }\end{array}$ & $\begin{array}{c}50(27) \$ \\
5(10)\end{array}$ & $\begin{array}{c}17(17) \\
0(0)\end{array}$ & $\begin{array}{l}55(25) \$ \S \\
1(2)\end{array}$ & $\begin{array}{l}32(11)^{\ddagger} \\
13(15)^{ \pm *}\end{array}$ \\
\hline
\end{tabular}

$* \%$ refers to percentage of total tissue area.

${ }^{* *} \mathrm{p}<0.01$ for difference from all three groups.

$+t \mathrm{p}<0.01$ for difference from both current smoking groups.

$\ddagger \mathrm{p}<0.05$ for difference from current smokers with mucus hypersecretion.

$\S \mathrm{p}<0.05$ for difference from ex-smokers without mucus hypersecretion.

$\$ \$ p<0.01$ for difference from ex-smokers without mucus hypersecretion. 
3), as well as a more severe degree of emphysema and greater smooth muscle hypertrophy in the membranous bronchioles. Current smokers without mucus hypersecretion showed greater goblet cell metaplasia than ex-smokers without mucus hypersecretion and greater squamous cell metaplasia than current smokers with chronic bronchitis. Both groups of current smokers had more intraluminal macrophages than ex-smokers with chronic bronchitis.

\section{Discussion}

The data reported here (see table 2) show that central airways are composed of roughly $18-20 \%$ cartilage, $73-76 \%$ connective tissue, $4-5 \%$ glands, and $1-2 \%$ muscle, values that agree with those of previous reports. ${ }^{15-19}$ Although the relationship of smoking to mucous gland size is not well established, there is a trend for cigarette smokers to have larger glands. ${ }^{1-4}$ The inability to detect a decrease in either mucous gland size or the Reid index after cessation of cigarette smoking is consistent with the findings of Seltzer and colleagues. ${ }^{20}$ They reported that in the recovery period after short term sulphur dioxide exposure gland acinar diameter, reflecting cellular activity, was partially reversible while gland acinar number, reflecting cellular proliferation, reverted slowly if at all. Mucous gland proportion may be a less sensitive measure of mucous gland size than either acinar diameter or acinar number and may therefore not reflect small but significant alterations in the mucous secreting apparatus after smoking has stopped.

Goblet cell metaplasia is a non-specific response of $\frac{}{\circ}$ the bronchial tree to irritants, and both animal and $\bar{\omega}$. human studies show increases in number ${ }^{21}$ and $\vec{\nabla}$ degree of peripheral extension ${ }^{22}$ of goblet cells in 0 response to cigarette smoke exposure. Seltzer and ${ }^{\text {कs }}$ colleagues ${ }^{20}$ described a mild to severe infiltrate of $\vec{O}$ mononuclear cells around bronchi during chronic $\vec{\longrightarrow}$ (6-18 months) exposure to sulphur dioxide, which ${ }_{\stackrel{\omega}{~}}$ was reduced in the recovery phase. These authors sug- $₹$ gested that goblet cell metaplasia in the airway may be secondary to the inflammatory process, rather $\vec{N}$ than a direct result of the inhaled insult. This concept $\overrightarrow{-}$ is consistent with that put forward by Florey ${ }^{23}$ con-o cerning inflammatory processes of mucous mem- $\vec{\omega}$ branes. In our study current smokers with mucus음 hypersecretion had the greatest values for central air- way goblet cell metaplasia, and greater values for cen- $z$ tral airway mucosal inflammation than ex-smokers without hypersecretion. The central airway inflammatory process was also present in the ex-黑 smokers who continued to have mucus hyper- $\vec{\bullet}$ secretion and was accompanied by inflammationo around the glands. In contrast, the ex-smokers who did not have mucus hypersecretion tended to have the least evidence of central airways inflammation.

The key feature of the peripheral airways data is that patients with mucus hypersecretion that persisted

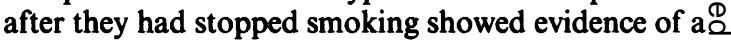
greater inflammatory response in both membranous $\overrightarrow{\vec{O}}$ and respiratory bronchioles. Although the number of $\exists$

Table 3 Peripheral airways data (mean (SD) scores)

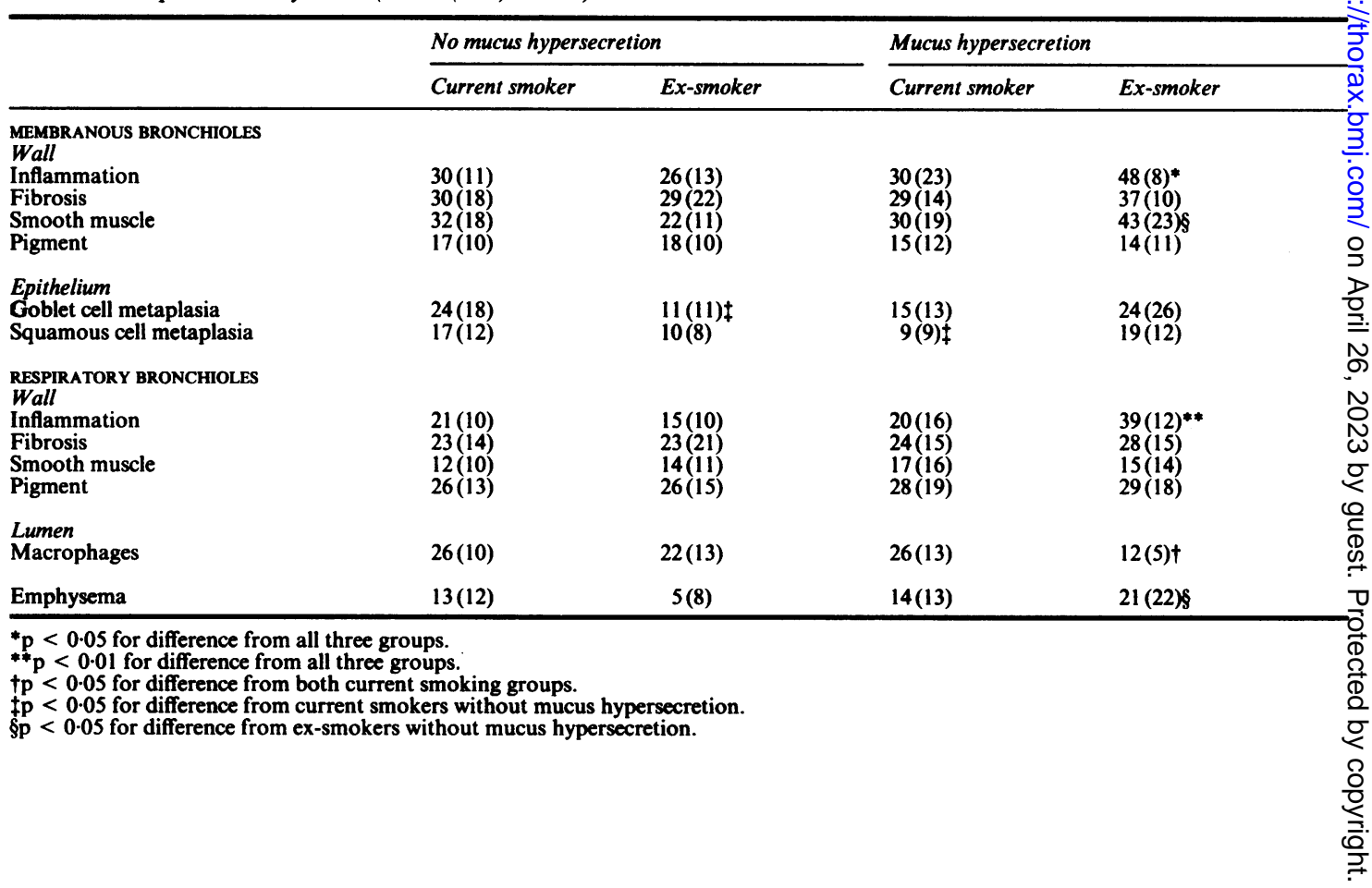


cases is small, these findings are consistent with the idea that mucus hypersecretion does not predict the presence of peripheral airways disease in current smokers, but they do suggest that patients whose mucus hypersecretion persists after they have stopped smoking may have an extensive inflammatory process affecting both the central and the peripheral airways.

The presence of increased central airway inflammation in mucus hypersecretion has not been well recognised. Previous studies ${ }^{24-27}$ have shown that airway inflammation is slight in mucus hypersecretion and does not distinguish those with hypersecretion from controls. Martin and coworkers, ${ }^{28}$ using a grading scheme similar to ours, found a significant relationship between airway inflammation and the presence of cough but not sputum production. Central airway inflammation has also been associated with panlobular emphysema. ${ }^{29}$ In this study, although the ex-smokers with mucus hypersecretion had significantly higher emphysema scores, it was mild and primarily centrilobular.

Peripheral airways inflammation has not generally been considered to be a component of mucus hypersecretion, although Matsuba and Thurlbeck ${ }^{30}$ showed airway structural changes when lungs from patients with and without mucus hypersecretion were compared.

Previous studies have suggested that the rate of decline in pulmonary function decreases or that function may actually improve after cessation of smoking. ${ }^{31-35}$ Although our study does not provide longitudinal data, it is of interest that those who had stopped smoking and continued to have mucus hypersecretion had a greater slope of phase 3 of the nitrogen washout curve $\left(\Delta \mathrm{N}_{2} / \mathrm{l}\right)$ than any of the other groups. As the slope of phase 3 of the nitrogen washout response has recently been shown to predict the decline in $\mathrm{FEV}_{1},{ }^{36}$ possibly patients with persistent mucus hypersecretion after cessation of smoking have a more severe inflammatory response in both central and peripheral airways that may ultimately lead to airways obstruction.

\section{References}

1 Scott KWM. An autopsy study of mucous gland hypertrophy in Glasgow. Am Rev Respir Dis 1973;107:239-45.

2 Cosio MG, Hale KA, Niewoehner DE. Morphologic and morphometric effects of prolonged cigarette smoking on the small airways. Am Rev Respir Dis 1980;122:265-71.

3 Thurlbeck WM, Angus GE, Paré JAP. Mucous gland hypertrophy in chronic bronchitis, and its occurrence in smokers. Br J Dis Chest 1963;57:73-8.
4 Ryder RC, Dunnill MS, Anderson JA. A quantitative study of the bronchial mucous gland volume, emphysema and smoking in a necropsy population. $J$ Pathol 1971;104:59-71.

5 Mullen JBM, Wright JL, Wiggs BR, Hogg JC. Reassessment of inflammation of airways in chronic bronchitis. Br Med J 1985;291:1235-9.

6 DuBois AB, Botelho SY, Bedell GW, Marshall R, Comroe JH. A rapid plethysmographic method for measuring thoracic gas volume: a comparison with a nitrogen washout method for measuring functional residual capacity in normal subjects. $J$ Clin Invest 1956;35:322-6.

7 Buist AUL, Ross BB. Quantitative analysis of the alveolar plateau in the diagnosis of early airway obstruction. Am Rev Respir Dis 1973;108:1078-87.

8 Morris JF, Koski A, Johnson LC. Spirometric standards for healthy non-smoking adults. Am Rev Respir Dis 1971;103:57-67.

9 Dosman J, Bode F, Urbanetti J, Martin R, Macklem PT. The use of a helium-oxygen mixture during expiratory flow to demonstrate obstruction in small airways in smokers. J Clin Invest 1975;55:1090-9.

10 Bates DV, Woolf CR, Paul GI. Chronic bronchitis: a report on the first two stages of the coordinated study of chronic bronchitis in the Department of Veterans Affairs, Canada. Med Serv J Can 1962;18:211-303.

11 Cosio M, Ghezzo $\mathrm{H}$, Hogg JC, et al. The relations between structural changes in small airways and pulmonary-function tests. $N$ Engl $J$ Med 1978;298:1277-81.

12 Wright JL, Cosio M, Wiggs B, Hogg JC. A morphologic grading scheme for membranous and respiratory bronchioles. Arch Pathol Lab Med 1985;109:163-5.

13 Wright JL, Paré PD, Wiggs B, Hogg JC. Ranking the severity of emphysema on whole lung slices: concordance of upper lobe, lower lobe, and entire lung ranks. Am Rev Respir Dis 1986;133:930-1.

14 Ciba Guest Symposium. Terminology, definitions and classifications of chronic pulmonary emphysema and related conditions. Thorax 1959;14:286-99.

15 Hale FC, Olsen CR, Mickey MR. The measurements of bronchial wall components. Am Rev Respir Dis 1968;98:978-87.

16 Dunnill MS, Massarella GR, Anderson JA. A comparison of the quantitative anatomy of the bronchi in normal subjects, in status asthmaticus, in chronic bronchitis, and in emphysema. Thorax 1969;24:176-9.

17 Takizawa T, Thurlbeck WM. Muscle and mucous gland size in the major bronchi of patients with chronic bronchitis, asthma and asthmatic bronchitis. Am Rev Respir Dis 1971;104:331-6.

18 Niewoehner DE, Kleinerman J, Knoke JD. Regional chronic bronchitis. Am Rev Respir Dis 1972;105:586-93.

19 Oberholzer M, Dalquen P, Huber M, et al. Stereology, a complement to respiration research bronchus morphometry: methodology and baseline data. Microsc Acta 1977;79:205-23.

20 Seltzer J, Scanlon PD, Drazen JM, Ingram RH Jr, Reid L. Morphologic correlation of physiologic changes caused by $\mathrm{SO}_{2}$-induced bronchitis in dogs. 
The role of inflammation. Am Rev Respir Dis 1984;129:790-7.

21 Hayashi M, Sornberger GC, Huber GL. Differential response in male and female tracheal epithelium following exposure to tobacco smoke. Chest 1978;73:515-8.

22 Wright JL, Lawson LM, Paré PD, Wiggs BJ, Kennedy S, Hogg JC. Morphology of peripheral airways in current smokers and ex-smokers. Am Rev Respir Dis 1983;127:474-7.

23 Florey H. General pathology. 3rd ed. London: LloydLuke, 1962.

24 Reid L. Measurement of the bronchial mucous gland layer: a diagnostic yardstick in chronic bronchitis. Thorax 1960;15:132-41.

25 Reid L. Pathology of chronic bronchitis. Lancet 1954;i:275-8.

26 Field WEH, Davey EN, Reid L, Roe FJC. Bronchial mucous gland hypertrophy: its relation to symptoms and environment. Br J Dis Chest 1966;60:66-80.

27 Salvato G. Some histological changes in chronic bronchitis and asthma. Thorax 1968;23:168-72.

28 Martin CJ, Katsura S, Cochran TH. The relationship of chronic bronchitis to the diffuse obstructive pulmonary syndrome. Am Rev Respir Dis 1970;102:362-9.

29 Linhartova A, Anderson AE Jr, Foraker AG. Site predilection of airway inflammation by emphysema type.
Arch Pathol Lab Med 1984;108:662-5.

30 Matsuba K, Thurlbeck WM. Disease of the small airways in chronic bronchitis. Am Rev Respir Dis 197’; 107:552-8.

31 Tashkin DP, Clark VA, Coulson AH, et al. The UCLA population studies of chronic obstructive respiratoryes disease. VIII. Effects of smoking cessation on lung $\vec{\circ}$ function: a prospective study of a free-living popu-: lation. Am Rev Respir Dis 1984;130:707-15.

32 Fletcher C, Peto R, Tinker C, Speizer FE. The natural history of chronic bronchitis and emphysema. An $\overrightarrow{\times}$ eight-year study of early chronic obstructive disease in working men in London. New York: Oxford University? Press, 1976:70-105.

33 Bosse R, Sparrow D, Rose CL, Weiss ST. Longitudinal $\vec{\infty}$ effect of age and smoking cessation on pulmonary $\vec{\omega}$ function. Am Rev Respir Dis 1981;123:378-81.

34 Bosse R, Sparrow D, Garvey AJ, Costa PT Jr, Weiss ST, Rowe JW. Cigarette smoking, aging, and decline in $Z$ pulmonary function: a longitudinal study. Arch Envi-O ron Health 1980;35:247-52.

35 Ashley F, Kannel WB, Sorlie PD, Masson R. Pulmonary function: relation to aging, cigarette habit, and mor-黑 tality. The Framingham Study. Ann Intern Med 1975;82:739-45.

36 Olofsson J, Boke B, Svardsudd K, Skoogh BE. The sin-.gle breath $\mathrm{N}_{2}$ test predicts the rate of decline in $\mathrm{FEV}_{1}$. Eur J Respir Dis 1986;69:46-56. 